\title{
PENINGKATAN KINERJA LINI PERAKITAN MANUAL DENGAN PENDEKATAN LEAN-KAIZEN
}

\author{
Famila Dwi Winati \\ Prodi Teknik Industri, Fakultas Rekayasa Industri dan Desain, Institut Teknologi Telkom Purwokerto \\ Email : familadw@ittelkom-pwt.ac.id
}

\begin{abstract}
Abstrak, Lean manufacturing merupakan sebuah konsep yang sering digunakan oleh industri untuk mencapai keunggulan kompetitif dengan cara mengurangi pemborosan yang tidak memberi nilai tambah dengan biaya yang minimal. Penelitian ini bertujuan untuk meningkatkan performansi lini perakitan manual yang menghadapi kesulitan untuk mendapatkan performansi maksimum dengan pendekatan Lean-Kaizen. Current state VSM menggambarkan kondisi lini perakitan saat ini guna mengidentifikasi pemborosan yang terjadi dan memfokuskan area perbaikan menggunakan Kaizen. Arah utama strategi Kaizen yang diterapkan yaitu mengurangi waktu siklus serta kegiatan yang tidak memberi nilai tambah dan dideskripsikan melalui future state VSM. Hasilnya, penerapan Lean-Kaizen terbukti secara signifikan dapat meningkatkan produksi harian dan produktivitas lini perakitan.
\end{abstract}

Kata kunci : lean manufacturing, Kaizen, lini perakitan, VSM, performansi

\section{PENDAHULUAN}

Pertumbuhan dan perkembangan industri saat ini memicu timbulnya persaingan antar perusahaan. Persaingan ini menuntut tiap perusahaan untuk memenuhi permintaan konsumen dengan kualitas yang tinggi, namun dengan biaya produksi yang minimum. Sehingga, agar perusahaan tetap kompetitif, dibutuhkan cara-cara baru untuk mengurangi biaya dan meningkatkan kualitas (Prashar, 2014). Salah satu konsep yang dapat diterapkan untuk mencapai keunggulan kompetitif ini adalah lean manufacturing. Konsep lean telah banyak diimplementasikan oleh perusahaan di seluruh dunia karena memiliki keunggulan dalam hal biaya, kualitas, dan efisiensi yang ditawarkan (Sivaraman et al., 2020).

Lean adalah bagian dari Toyota Production System (TPS) yang diperkenalkan pertama kali oleh Taiichi Ohno pada tahun 1950-an. Fokus utama dari praktik lean adalah mengurangi pemborosan (waste) pada proses produksi. Pemborosan dalam proses produksi dikategorikan ke dalam delapan jenis, yaitu produk cacat (defects), kelebihan produksi (over production), waktu tunggu (waiting), kemampuan SDM yang tidak dimanfaatkan (underutilized people), persediaan (inventory), proses berlebihan (over processing), perpindahan material (transportation), dan gerakan yang tidak perlu (excess motion) (Douglas et al., 2015). Di banyak proses industri, aktivitas yang tidak memberikan nilai tambah (non-value added) mencapai lebih dari
90\% dari total aktivitas (Sutharsan et al., 2020) Untuk mencapai lean manufacture, segala bentuk aktivitas yang tidak memberikan nilai tambah (non-value added) dan pemborosan ini akan dieliminasi.

Lini perakitan adalah bagian dari sistem produksi yang terdiri sejumlah stasiun kerja yang disusun pada jalur dan tata letak tertentu (Karas \& Ozcelik, 2021). Pada lini perakitan, barang setengah jadi bergerak di sepanjang jalur, dimana masing-masing stasiun kerja memiliki operator atau mesin dengan tugas tertentu. Saat ini, proses perakitan pada sebagian besar manufaktur masih dilakukan secara manual dengan sedikit sekali pengaruh otomasi (Usubamatov et al., 2013). Hal ini disebabkan karena pengoperasian perakitan otomatis sangat kompleks dan membutuhkan biaya yang tinggi. Meskipun bersifat konvensional, pada sistem produksi yang memiliki variasi produk yang tinggi, lini perakitan manual menawarkan fleksibilitas dan kemudahan dalam pengoperasiannya dibandingkan dengan lini perakitan yang terotomatisasi (Yerasi, 2011). Perakitan manual menjadi salah satu solusi optimal untuk menghasilkan beberapa varian produk yang berasal dari struktur produk umum (Correia $e t$ al., 2018).

Masalah yang sering dihadapi oleh lini perakitan yang secara penuh bergantung pada manusia/operator adalah potensi untuk mendapatkan produktivitas dan efisiensi maksimum masih sangat terbatas (Miqueo et 
al., 2020). Salah satu penyebabnya adalah kemampuan antar operator yang berbeda satu sama lain, sehingga produksi tidak bekerja pada kecepatan yang konstan (Karas \& Ozcelik, 2021; Usubamatov et al., 2013). Ketidakselarasan ini akan menimbulkan pemborosan pada proses produksi, seperti munculnya waktu tunggu dan secara tidak langsung menghasilkan aktivitas-aktivitas yang tidak menambah nilai. Oleh karena itu, penelitian ini berfokus untuk meningkatkan produktivitas dengan mengeliminasi pemborosan dan aktivitas non-value added.

Secara global, berbagai macam industri telah mengimplementasikan lean manufacturing dan terbukti memberikan keunggulan kompetitif dan meningkatkan profit. Beberapa penelitian terdahulu juga menunjukkan bahwa pengimplementasian lean tools secara signifikan mengurangi cycle time, lead time, persediaan, handling, gerakan yang tidak penting, hingga pengurangan ruang dan lantai produksi yang berdampak pada peningkatan produktivitas dan kualitas (Chowdary \& George, 2011; Kundgol et al., 2020; Oliveira et al., 2019; Pena et al., 2020; Ravizar \& Rosihin, 2018). Intinya, pengurangan pemborosan adalah prinsip dasar dari penerapan lean manufacturing dengan berfokus pada aktivitas-aktivitas yang memberi nilai tambah (value added) berdasarkan sudut pandang konsumen (Ruben et al., 2019). Aktivitas yang memberi nilai tambah adalah seluruh kegiatan yang mempengaruhi keinginan untuk membeli (willingness to pay) konsumen.

Value Stream Mapping (VSM) adalah teknik dari lean manufacturing yang sering diterapkan di hampir seluruh sektor industri karena mudah digunakan dan mendukung implementasi lean (Romero \& Arce, 2017). VSM adalah alat untuk menggambarkan aliran material dan informasi di sepanjang proses produksi secara detil dan mengidentifikasi seluruh aktivitas yang memberi atau tidak memberi nilai tambah (Sutharsan et al., 2020). Melalui VSM, akan didapatkan informasi mengenai aktivitas-aktivitas pemborosan dan dianalisis lanjut sebagai dasar untuk melakukan perbaikan. Selanjutnya, perbaikan yang dilakukan akan berorientasi pada proses dan hasil dengan mengacu pada pereduksian pemborosan tersebut. Konsep ini dikenal dengan istilah Kaizen (Prashar, 2014). Kaizen adalah sebuah konsep perbaikan berkelanjutan (continuous improvement) untuk mencapai kinerja yang tinggi dengan biaya yang relatif rendah dibandingkan inovasi (Kiran, 2017). Filosofi Kaizen ini bermakna bahwa selalu ada cela untuk perbaikan dan menghasilkan sistem yang lebih baik.

Telah banyak literatur yang secara ekstensif mengkaji implementasi lean manufacturing di berbagai sektor manufaktur, namun masih sedikit literatur yang membahas hal ini pada bagian perakitan secara khusus (Sutharsan et al., 2020). Adapun literatur yang membahas mengenai implementasi lean pada lingkungan perakitan, sebagian besar masih terpaku pada proses-proses yang bersifat otomatis (automated process) (Domingo et al., 2009; Nguyen \& Do, 2016), bukan perakitan manual. Oleh karena itu, fokus penelitian adalah pengimplementasian Lean-Kaizen pada proses perakitan manual. Karena keterlibatan manusia dalam proses cukup besar, sehingga meningkatkan potensi terjadinya pemborosan dan kerugian, seperti waktu proses yang lebih panjang dan produk cacat yang secara kualitas tidak memenuhi standar (Klimecka-Tatar \& Shinde, 2019).

Penelitian ini bertujuan untuk meningkatkan produktivitas dengan mengurangi pemborosan dan aktivitas produksi yang tidak memberi nilai tambah dengan pendekatan Lean-Kaizen. VSM digunakan untuk memvisualisasikan proses produksi pada lini perakitan alat musik piano untuk mengetahui titik-titik dimana Kaizen akan diimplementasikan. Adapun secara garis besar, penelitian ini disusun sebagai berikut : bagian 2 berisi metode penelitian yang akan digunakan dan permasalahan khusus yang dihadapi oleh lini perakitan perusahaan. Bagian 3 akan menjelaskan hasil dan analisis dari implementasi lean manufacturing dan dampaknya bagi perusahaan. Sedangkan bagian 4 berisi kesimpulan dan saran untuk penelitian selanjutnya.

\section{METODE}

Penelitian ini menerapkan pendekatan Lean-Kaizen untuk meningkatkan produktivitas pada salah satu section lini perakitan piano. Karena prosesnya yang membutuhkan ketelitian, pekerjaan perakitan didominasi oleh operator dengan sedikit bantuan alat dan mesin. Data dikumpulkan melalui observasi langsung di lini perakitan. Selain itu, data sekunder juga dibutuhkan untuk 
mendukung proses analisis penelitian ini. Current state VSM dipetakan untuk mengidentifikasi pemborosan dan aktivitas non-value added yang terjadi di lini perakitan. Kemudian Kaizen diterapkan pada titik-titik tertentu dan digambarkan melalui future state VSM.

\section{Deskripsi Proses Lini Perakitan}

Bagian perakitan yang menjadi objek dalam penelitian ini memiliki 2 jalur perakitan yang aktif digunakan. Masing-masing lini terdiri dari tujuh stasiun kerja utama untuk melakukan perakitan komponen-komponen mekanik piano secara manual. Jumlah proses utama pada bagian ini adalah delapan proses, namun proses pada WS 6, yaitu seasoning tidak membutuhkan stasiun kerja dan operator khusus. Selain itu, terdapat bagian tambahan di luar lini perakitan, yaitu part picking yang bertugas untuk mengatur komponen yang dikirim dari gudang ke dalam tray dan dibagikan pada masing-masing WS.

Total operator yang berperan pada bagian perakitan ini adalah 16 orang. Ketiga lini perakitan pada bagian ini memiliki jumlah dan proses yang sama, sehingga secara total jumlah stasiun kerja adalah 24 stasiun. WS 1 adalah proses setting action terdiri dari dua orang yang secara bergantian bekerja di ketiga lini. WS 2 hingga WS 5 berturut-turut adalah proses setting damper block, pasang damper, soange, dan pasang hammer. Empat WS ini dipegang oleh dua kelompok kerja yang tiap kelompok terdiri dari 4 orang dan bertanggung jawab pada ketiga lini. Selanjutnya, WS 7 dan WS 8 merupakan proses setting keyboard dan key level dipegang oleh tiga kelompok kerja yang masing-masing terdiri dari dua operator.

\section{Masalah Khusus Lini Perakitan}

Penelitian ini bertujuan untuk meningkatkan produktivitas dengan mengeliminasi aktivitas-aktivitas non-value added pada salah satu perusahaan pembuatan alat musik di Indonesia dengan produk utama piano. Permasalahan utama yang dihadapi oleh bagian ini adalah target harian yang seringkali tidak tercapai selama 8 jam waktu kerja yaitu sebanyak 92 unit yang dapat dilihat pada Gambar 1.

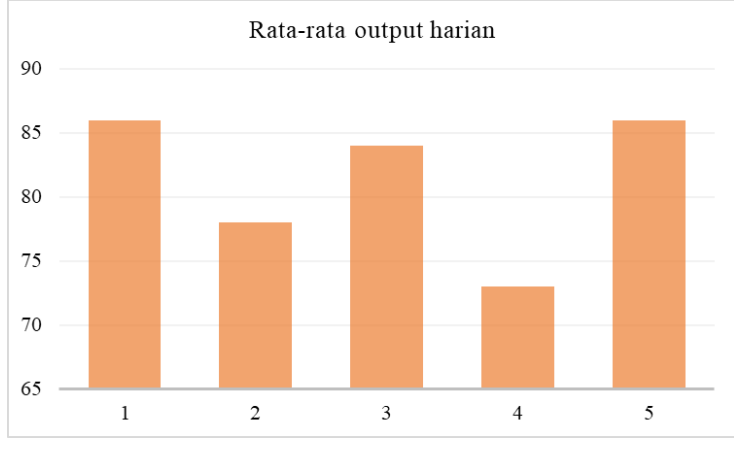

Gambar 1. Rata-rata output harian

Ketidaktercapaian target ini dipengaruhi oleh proses perakitan yang masih dilakukan secara manual, sehingga kecepatan pengerjaan tiap operator berbeda-beda. Oleh karena itu, dibutuhkan alternatif solusi untuk mencapai target harian, yaitu melalui overtime atau transfer tenaga kerja dari bagian lain. Namun, hal ini berpengaruh terhadap pencapaian produktivitas, dimana input (tenaga kerja dan jam kerja) semakin besar, sedangkan output berupa unit piano yang dihasilkan tidak berubah secara signifikan akan mengakibatkan produktivitas menjadi rendah. Keadaan awal saat pengamatan dimulai, produktivitas lini perakitan ini adalah sebesar 0,61, sedangkan produktivitas ideal yang ditargetkan oleh perusahaan adalah 0,7. Melalui pendekatan Lean-Kaizen, diharapkan terjadi kenaikan produktivitas dan target harian terpenuhi.

\section{Tahap Implementasi Lean-Kaizen}

Tahap penelitian ini dapat dilihat pada Gambar 2. Pengumpulan data yang berhubungan dengan proses produksi pada lini perakitan adalah tahap pertama dalam penelitian ini. Data yang dikumpulkan akan digunakan untuk menggambarkan aliran produk dan informasi pada kondisi saat ini. Current state VSM menggambarkan kondisi awal lini perakitan.

Sebelum mengetahui secara eksplisit perbaikan apa yang harus dilakukan, diperlukan diskusi lebih lanjut dengan pihak-pihak yang bersangkutan, seperti Ketua Kelompok, operator, dan manajer produksi. Hal ini dilakukan untuk menangkap lebih banyak informasi mengenai penyebab terjadinya penurunan produktivitas dan ketidaktercapaian target harian. Fishbone diagram digunakan untuk menganalisis akar masalah. Setelah mengetahui secara pasti permasalahan yang dihadapi oleh bagian perakitan, maka Kaizen 
yang akan diimplementasikan dapat ditentukan secara pasti. Setelah perbaikan dilakukan melalui rencana-rencana Kaizen, akan dianalisis dampak dari pengimplementasian Lean-Kaizen terhadap produktivitas dan ketercapaian target produksi. Lebih lanjut, dampak terhadap waktu produksi, persediaan, hingga kebutuhan operator juga dapat diketahui.

Selanjutnya gambaran ideal mengenai aliran produksi ditunjukkan melalui future state VSM untuk mengidentifikasi dimana titik-titik Kaizen akan dilakukan. Tujuannya adalah untuk mengetahui lebih lanjut pemborosan dan aktivitas-aktivitas non-value added yang harus dieliminasi dari keseluruhan proses.

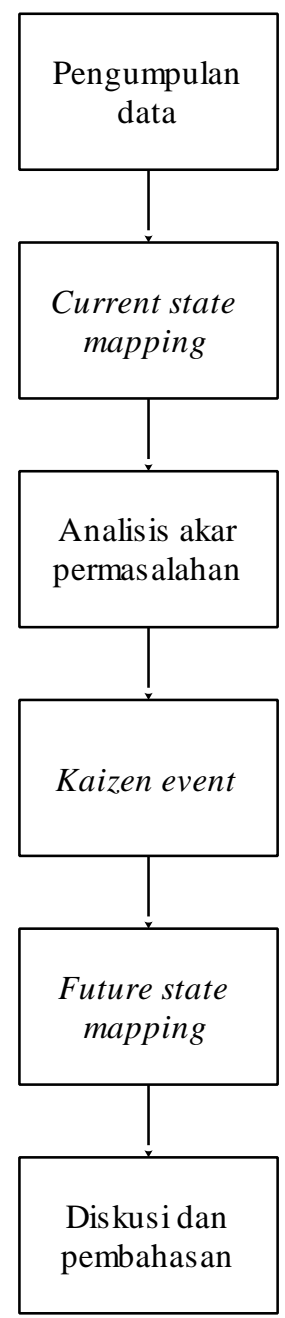

Gambar 2. Tahap Implementasi Lean-Kaizen

\section{HASIL DAN PEMBAHASAN \\ Current State VSM}

Current state map memberikan deskripsi gambaran proses produksi yang sedang berjalan saat ini. Penyusunan current state VSM dijabarkan dalam beberapa tahap, dimulai dari penentuan Value Stream Manager, pembuatan diagram SIPOC, hingga pembuatan overall current state VSM (Nasution et al., 2018).

\section{Value Stream Manager}

Seseorang atau pihak yang bertanggungjawab dan memahami mengenai keseluruhan proses disebut Value Stream Manager. Dalam penelitian ini, Value Stream Manager yang dipilih adalah Kepala Kelompok pada salah satu lini perakitan manual yang dijadikan objek penelitian. Kepala Kelompok memiliki peran penting dalam pengambilan keputusan di lini perakitan, mampu memberikan informasi secara lengkap, dan memberi saran terkait perbaikan yang dapat diterapkan.

\section{Formulasi Diagram SIPOC}

Diagram SIPOC adalah sebuah diagram informatif yang memberikan informasi dan deskripsi yang relevan mengenai Supplier, Input, Process, Output, dan Customer yang terlibat dalam sistem produksi. Diagram SIPOC adalah salah satu alat lean yang secara luas digunakan dalam mendiagnosa proses, meningkatkan perencanaan bisnis, re-engineering, hingga perbaikan berkelanjutan (Al-Aomar \& Hussain, 2018). Selain itu, Diagram SIPOC memudahkan peneliti untuk mengidentifikasi bentuk proses, pemborosan, dan praktik lean yang sedang diaplikasikan.

Elemen-elemen diagram SIPOC yang digunakan pada penelitian ini adalah sebagai berikut.

a. Supplier, terdiri dari gudang material, bagian part picking yang bertugas untuk menata kebutuhan material yang didapatkan dari gudang material ke dalam tray untuk dibagikan ke masingmasing stasiun kerja, dan section proses pengeleman bagian luar (cover) piano.

b. Input, terdiri dari piano yang telah memiliki body dan cover yang lengkap, material pendukung seperti hammer, action, screw, dan keyboard.

c. Process, terdiri dari proses-proses perakitan komponen-komponen mekanik piano hingga mengeluarkan bunyi, yaitu setting action, setting damper block, pasang damper, soange, pasang hammer, 
seasoning, setting keyboard, dan key level.

d. Output, berupa piano yang telah mampu mengeluarkan bunyi.

e. Customer, yaitu bagian Tuning yang bertugas untuk mengatur kesesuaian bunyi piano.
3. Current State Map VSM

Current state VSM dapat dilihat pada Gambar 3. Pesanan dari konsumen didapatkan dalam jangka waktu per bulan dengan jumlah yang konstan tiap bulannya, kemudian dijabarkan dalam bentuk target harian, yaitu 92 unit. Terdapat sembilan proses dengan delapan proses yang berada pada jalur perakitan utama.

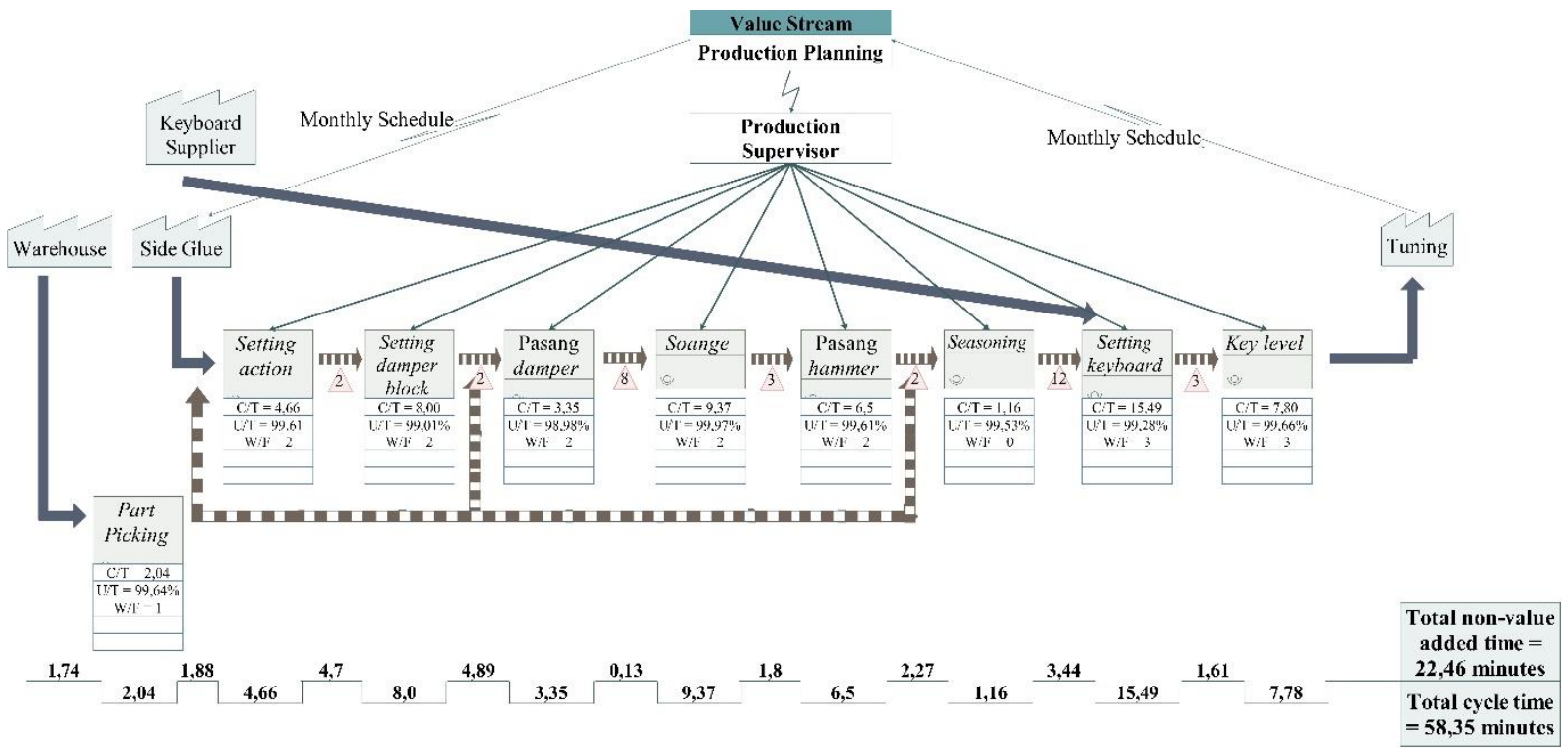

Gambar 3. Current State VSM

Terdapat dua acuan waktu utama yang dijabarkan dalam current state VSM, yaitu cycle time (CT) dan non-value added (NVA) time. CT merupakan waktu yang diperlukan untuk memproduksi dari awal hingga akhir untuk satu unit produk (Zahraee et al., 2020). CT merepresentasikan waktu operasi yang terdiri dari aktivitas-aktivitas yang memberikan nilai tambah. Pada jalur produksi, CT ditunjukkan dengan waktu operasi stasiun kerja yang paling lama, sehingga menunjukkan adanya indikasi bottleneck (Oliveira et al., 2019). Di antara seluruh operasi, cycle time tertinggi terdapat pada proses setting keyboard yaitu 15,49 menit dengan WIP atau persediaan antara proses hammer seasoning dan setting keyboard adalah 12 unit. Total CT untuk keseluruhan proses adalah 58,35 menit dengan total NVA mencapai 22,46 menit. Oleh karena itu, total waktu perakitan satu piano pada lini perakitan ini adalah 80,81 menit.

Selanjutnya, dilakukan process activity mapping untuk mengidentifikasi aktivitasaktivitas yang bernilai tambah ataupun tidak. Proses ini dapat membantu peneliti dalam mengidentifikasi pemborosan-pemborosan yang terjadi di dalam lini perakitan. Rekapitulasi pemetaan aktivitas dapat dilihat pada Tabel 1. Jumlah aktivitas yang dilakukan dalam proses perakitan adalah 145 aktivitas dengan perpindahan (transportasi atau handling) diukur dalam satuan langkah mencapai 222 langkah. Aktivitas didominasi oleh aktivitas operasi.

Tabel 1. Process Activity Mapping

\begin{tabular}{|l|c|c|}
\hline \multicolumn{1}{|c|}{$\begin{array}{c}\text { Jenis } \\
\text { Aktivitas }\end{array}$} & $\begin{array}{c}\text { Jumlah } \\
\text { Aktivitas }\end{array}$ & $\begin{array}{c}\text { Waktu } \\
\text { (menit) }\end{array}$ \\
\hline Operasi & 121 & 72,93 \\
\hline $\begin{array}{l}\text { Transportasi } \\
\text { (handling) }\end{array}$ & 15 & 5,54 \\
\hline Inspeksi & 8 & 2,31 \\
\hline $\begin{array}{l}\text { Penyimpanan } \\
\text { (storage) }\end{array}$ & 1 & 0,03 \\
\hline Delay & 0 & 0 \\
\hline Total & 145 & 80,81 \\
\hline Perpindahan & \multicolumn{2}{|c|}{271 langkah } \\
\hline
\end{tabular}

Salah satu elemen penting dalam lean manufacturing adalah takt time, yaitu waktu 
yang digunakan sebagai acuan untuk menyesuaikan tingkat produksi seharusnya dengan tingkat permintaan (Hamed \& Soliman, 2020). Takt time menunjukkan seberapa sering produksi dilakukan agar dapat memenuhi permintaan pelanggan (Nasution et al., 2018). Takt time dihitung dengan membagi waktu operasional efektif atau available time dengan jumlah permintaan dalam periode tertentu. Waktu operasional perusahaan adalah 8 jam per hari, atau sama dengan 460 menit per hari dengan target produksi harian adalah 92 unit. Oleh karena itu, takt time yang digunakan pada lini perakitan ini mengikuti standar perusahaan, yaitu 5 menit. Perbandingan cycle time dan takt time dapat dilihat pada Tabel 2.

Tabel 2. Perbandingan Cycle Time dan Takt Time

\begin{tabular}{|l|c|c|}
\hline \multicolumn{1}{|c|}{ Proses } & $\begin{array}{c}\text { Cycle Time } \\
\text { (menit) }\end{array}$ & $\begin{array}{c}\text { Takt Time } \\
\text { (menit) }\end{array}$ \\
\hline Setting action & 4,66 & 5,00 \\
\hline $\begin{array}{l}\text { Setting } \\
\text { damper block }\end{array}$ & 8,00 & 5,00 \\
\hline $\begin{array}{l}\text { Pasang } \\
\text { damper }\end{array}$ & 3,35 & 5,00 \\
\hline Soange & 9,37 & 5,00 \\
\hline $\begin{array}{l}\text { Pasang } \\
\text { hammer }\end{array}$ & 6,50 & 5,00 \\
\hline Seasoning & 1,16 & 5,00 \\
\hline $\begin{array}{l}\text { Setting } \\
\text { keyboard }\end{array}$ & 15,49 & 5,00 \\
\hline Key level & 7,80 & 5,00 \\
\hline
\end{tabular}

Ketika CT berada di bawah takt time, dapat disimpulkan bahwa proses berjalan lebih cepat dari yang seharusnya dan dapat memenuhi semua permintaan. Namun, pada current state VSM ini dapat dilihat bahwa proses berjalan lebih lambat dari yang seharusnya sehingga menyebabkan target harian seringkali tidak terpenuhi dan bottleneck di proses tertentu. Hal ini juga menyebabkan Kepala Kelompok terpaksa mengambil keputusan untuk melakukan overtime atau transfer operator dari bagian lainnya. Keputusan ini tentu saja berimplikasi pada produktivitas lini perakitan yang menurun.

\section{Analisis Akar Permasalahan}

Tujuan utama dari penelitian ini adalah meningkatkan kinerja perusahaan yang dapat diukur melalui produktivitas. Diagram
Fishbone digunakan pada penelitian ini untuk menganalisis penyebab risiko secara kualitatif. Diagram Fishbone terbukti dapat membuat sistem yang kompleks menjadi lebih terorganisir (Luo et al., 2018). Analisis akar permasalahan menggunakan diagram fishbone dapat dilihat pada Gambar 4. dengan permasalahan yang ingin dianalisis penyebabnya adalah target produktivitas yang tidak tercapai.

Gambar 4. menunjukkan lima permasalahan utama penyebab tidak tercapainya target produktivitas, yaitu waktu siklus, aktivitas NVA, operator, penggunaan input, dan kualitas. Setelah dianalisis lebih lanjut, penyebab utama permasalahan ini berada pada waktu CT yang cukup panjang, khususnya pada proses-proses tertentu. CT yang lama mengindikasikan adanya aktivitasaktivitas NVA yang melekat pada aktivitas utama (Nasution et al., 2018). Selain itu, proses-proses perakitan komponen mekanik piano membutuhkan ketelitian karena ukuran komponen yang kecil, serta seluruh proses masih dilakukan oleh manusia juga menjadi penyebab tinggi CT pada lini perakitan ini. Oleh karena itu, diperlukan perbaikan yang signifikan untuk mereduksi CT.

Beberapa akar permasalahan yang ditunjukkan pada Gambar 4. pada dasarnya memiliki keterkaitan satu sama lain. Salah satunya adalah aktivitas NVA yang cukup tinggi. Beberapa penyebabnya adalah sering terjadi bottleneck pada proses setting keyboard yang memiliki nilai CT tertinggi diantara seluruh proses perakitan. Selain itu, tingginya mobilitas operator di lantai produksi hanya untuk sekadar mengambil alat bantu yang letaknya jauh. Kurangnya alat bantu seperti jig dan gauge juga menjadi salah satu penyebab munculnya gerakan-gerakan (motions) yang tidak perlu dan tidak memberi nilai tambah. Tingginya NVA pada proses produksi menunjukkan terjadinya pemborosan berlebihan yang perlu dieliminasi.

Produktivitas dipengaruhi oleh dua aspek utama, yaitu penggunaan input dan output yang dihasilkan. Untuk memaksimalkan produktivitas, perlu dilakukan peningkatan output atau pengurangan jumlah input. Namun, pada lini perakitan manual ini, ditemukan adanya penggunaan input yang berlebihan sehingga berdampak pada capaian produktivitas. Input yang dipertimbangkan dalam analisis produktivitas penelitian ini 
adalah jumlah jam kerja, termasuk lembur dan jumlah tenaga kerja, termasuk kebijakan transfer in dan transfer out.

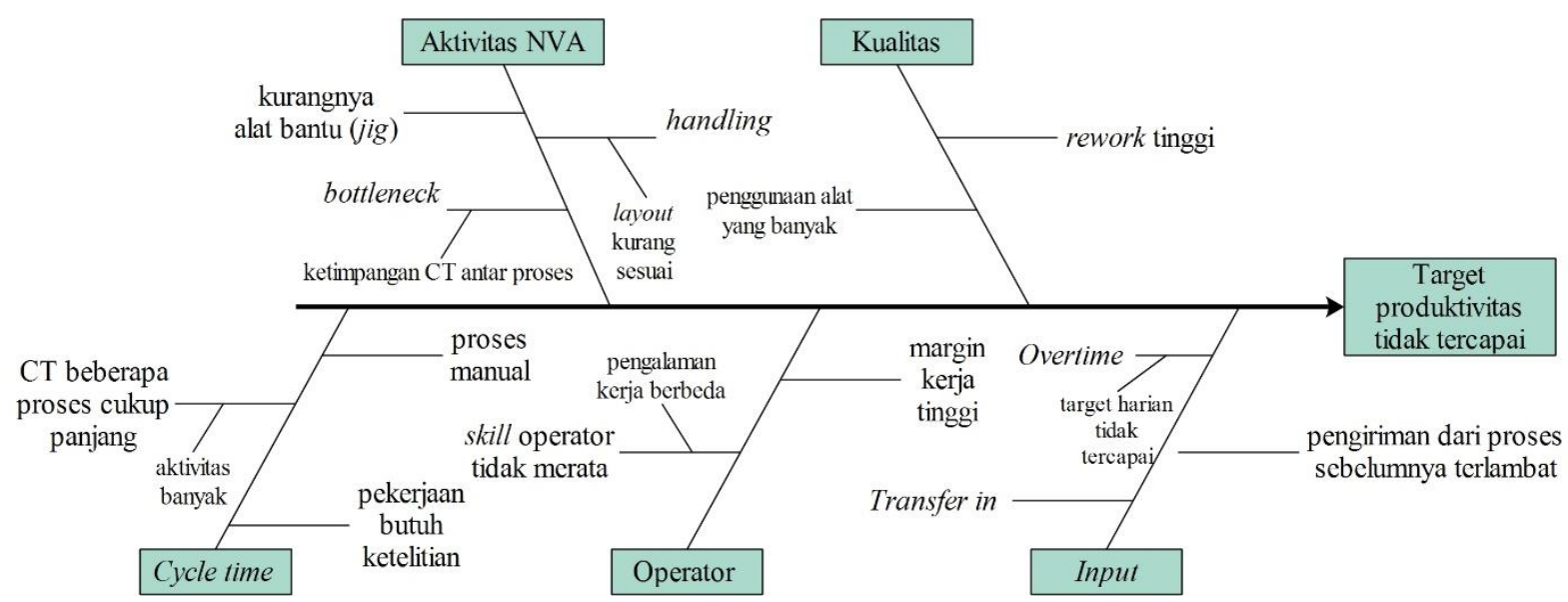

Gambar 4. Diagram Fishbone

Jam kerja efektif terhitung hanya 8 jam/hari. Jika diperlukan lembur, maka jam kerja akan bertambah 2,5 jam, sehingga total jam kerja adalah 10,5 jam/hari. Jumlah operator tetap pada lini perakitan adalah 16 orang. Transfer in dari bagian lain dilakukan jika jumlah operator tetap tidak mampu menyelesaikan 92 unit. Semakin tinggi jam kerja dan jumlah operator, maka produktivitas akan menurun, dan sebaliknya. Pada lini perakitan First Regulation, dalam waktu satu bulan ( 25 hari kerja), terdapat 14 hari dimana First Regulation tidak mampu memenuhi target harian.

Penyebab lainnya yaitu pada aspek operator, dimana skill tiap operator berbeda. Hal ini juga disebabkan perbedaan pengalaman antar operator, sehingga kemampuan dan penguasaan terhadap proses pun berbeda. Takt time lini perakitan ini adalah 5 menit, yang berarti bahwa setiap 5 menit harus ada piano yang selesai dirakit. Oleh karena itu, semua proses pada lini perakitan harus selesai dalam 5 menit. Karena perakitan dilakukan secara manual, setiap operator membutuhkan waktu yang berbeda pula untuk menyelesaikan satu proses, bahkan ketika proses yang dikerjakan sama. Gambar 5 menunjukkan perbandingan CT tiap operator.

Salah satu penghambat tercapainya target produktivitas pada lini perakitan manual ini adalah adanya produk yang harus melalui proses rework sebagai akibat dari ditemukannya cacat saat inspeksi. Selain itu, temuan cacat yang mempengaruhi kualitas salah satunya dipengaruhi oleh penggunaan alat yang sering berganti. Karena proses perakitan komponen mekanik melibatkan pekerjaan detil dan spesifik, sehingga setiap aktivitas seringkali membutuhkan jenis alat yang berbeda. Saat pergantian alat ini, seringkali secara tidak langsung memberi goresan dan bekas cacat pada unit produk. Walaupun pengaruh kualitas terhadap produktivitas pada lini perakitan tidak signifikan, namun melalui pendekatan Lean-Kaizen, diharapkan terjadi peningkatan menyeluruh yang mencakup peningkatan kualitas dan produktivitas secara bersamaan (Gidey et al., 2014).

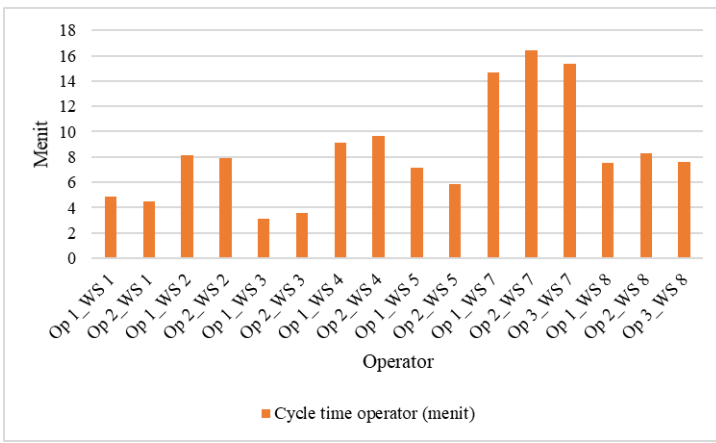

Gambar 5. Perbandingan CT Operator

\section{Rencana Kaizen}

Analisis pemborosan yang muncul pada lini perakitan, telah dilakukan melalui gambaran current state VSM. Berdasarkan penyebab-penyebab tidak tercapainya target produktivitas yang telah dijabarkan melalui Diagram Fishbone, akar masalah yang 
signifikan dan berpengaruh terhadap masalah lainnya adalah cycle time yang tinggi dan banyaknya aktivitas non-value added yang mencapai $28 \%$ dari total waktu perakitan tiap unit. Oleh karena itu, usulan perbaikan akan berfokus kepada pereduksian pemborosan untuk meminimalkan munculnya kedua masalah ini. Karena pada dasarnya, tiap permasalahan pada diagram Fishbone berkaitan satu sama lain, maka perbaikan yang terfokus pada cycle time dan aktivitas non-value added akan berdampak positif terhadap aspek masalah lainnya.

Selanjutnya, beberapa strategi LeanKaizen diusulkan untuk mengurangi pemborosan dan meningkatkan performansi lini perakitan melalui diskusi dengan ketua kelompok dan manajer produksi, yaitu sebagai berikut.

a. Perbaikan mesin yang digunakan untuk memasang sekrup pada WS 7 yang sebelumnya dilakukan secara manual, menjadi mesin pneumatik sehingga dapat mempercepat proses dan mengurangi beban operator.

b. Pengalihan penugasan pada WS 7 yang memiliki CT terbesar dari keseluruhan proses. Keyboard screwig pada WS 7 diambil alih oleh operator part picking. Hal ini juga dapat mengurangi waktu menganggur (idle) dari operator part picking yang memiliki beban paling sedikit di antara operator lainnya.

c. Perubahan instruksi kerja pada salah satu aktivitas di WS 3, dimana awalnya pengeleman dilakukan per tiga komponen menjadi enam komponen.

d. Modifikasi alat untuk memperbesar kapasitas pengeleman sehingga akan menurunkan CT pada WS 5.

e. Pemindahan lokasi WS 6 yaitu seasoning sehingga mengurangi proses handling.

f. Pengaturan lantai produksi untuk memberi ruang bergerak bagi operator dan mengurangi gerakan-gerakan yang tidak penting saat pergantian lini.

g. Re-layout dengan mengatur kembali letak mesin-mesin pendukung proses, dimana mesin-mesin diatur kembali sehingga berdekatan dengan WS yang berkaitan.

h. Peningkatan kecepatan operator dalam melakukan operasi sebagai bentuk pemerataan kemampuan. Hal ini dapat pula mengurangi jumlah produk cacat akibat kelalaian operator. i. Penambahan jig dan gauge untuk meminimalisir adanya unit yang tidak sesuai dengan standar. Penggunaan jig juga akan berpengaruh terhadap kecepatan proses.

j. Pengimplementasian prinsip 5S untuk menciptakan lingkungan kerja rapi, nyaman, dan aman. 5S merupakan cara sederhana dengan biaya yang minimal untuk mencapai manfaat lean (Omogbai \& Salonitis, 2017). Penerapan 5S juga akan mengurangi gerakan-gerakan yang tidak menambah nilai karena material dan alat yang tidak berada pada tempatnya atau lingkungan kerja yang kotor.

\section{Future State VSM}

Future state map digunakan untuk mendemonstrasikan kondisi lini perakitan setelah lean-Kaizen diimplementasikan. Future VSM juga dapat menjadi sebuah alat untuk terus meningkatkan performansi perusahaan. Future VSM ditunjukkan oleh Gambar 6 dengan mengimplementasikan usulan-usulan perbaikan pada current VSM untuk mengurangi pemborosan yang ditemukan dan meningkatkan produktivitas lini perakitan.

Penerapan Lean-Kaizen berdasarkan usulan perbaikan diproyeksikan memberi dampak yang signifikan terhadap pengurangan waktu operasi. Keberhasilan penerapan leankaizen dapat dilihat dari berkurangnya aktivitas-aktivitas yang tidak memberi nilai tambah, yang awalnya 64 menjadi 50 aktivitas. Secara kuantitas, implementasi yang dilakukan hanya mampu mengurangi $22 \%$ NVA. Namun, waktu NVA yang berhasil dikurangi mencapai $44 \%$, yaitu dari 22,46 menit menjadi 12,66 menit.

Pengurangan CT difokuskan pada WS yang memiliki CT tertinggi dan melebihi takt time, yaitu setting keyboard. Pembagian penugasan hingga modifikasi alat dilakukan sebagai upaya untuk mereduksi pemborosan dan waktu proses. Hasilnya, beban operator pada WS ini terbagi secara merata dan mereduksi CT proses hingga 71\%. Pembagian penugasan membantu mengurangi bottleneck pada proses ini. Adanya perbaikan dan perubahan mesin, alat, hingga penambahan jig dan gauge terbukti mengakselerasi waktu operasi di seluruh lini perakitan. Usulan ini terbukti dapat menurunkan CT masing-masing proses hingga 13 menit. Selain itu, adanya perbaruan alat dan mesin mampu menghilangkan beberapa aktivitas yang 
memberi nilai tambah hingga 6\%. Secara keseluruhan, terdapat penurunan waktu proses perakitan sebesar 28\% sebagai hasil dari implementasi Lean-Kaizen.

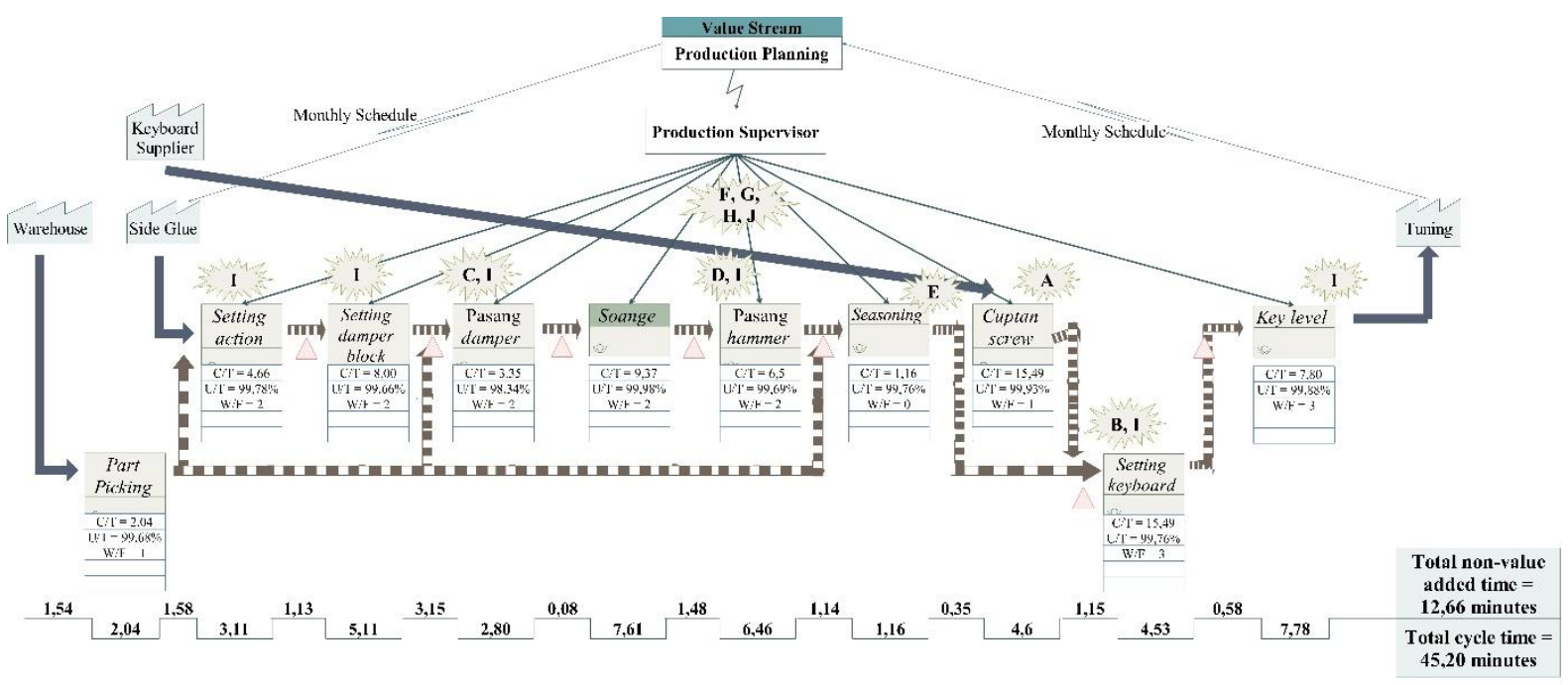

Keterangan:

Huruf-huruf pada ikon Kaizen Burst menunjukkan kaizen yang diimplementasikan pada proses tersebut.

Kaizen F, G, H, dan J diimplementasikan secara umum pada lini produksi

\section{Gambar 6. Future State VSM}

Perbandingan kinerja lini perakitan berdasarkan parameter lean sebelum dan sesudah penerapan Lean-Kaizen dapat dilihat pada Gambar 7. Pengurangan waktu operasi secara langsung dapat meningkatkan target harian tanpa harus melakukan penambahan input, seperti waktu lembur dan operator tambahan. Dengan pengurangan waktu proses, target harian diprediksi akan meningkat hingga 84 unit per hari. Apabila operator dapat mengeliminasi keseluruhan aktivitas-aktivitas yang tidak memberi nilai tambah, target harian diprediksi dapat mencapai 106 unit per hari.

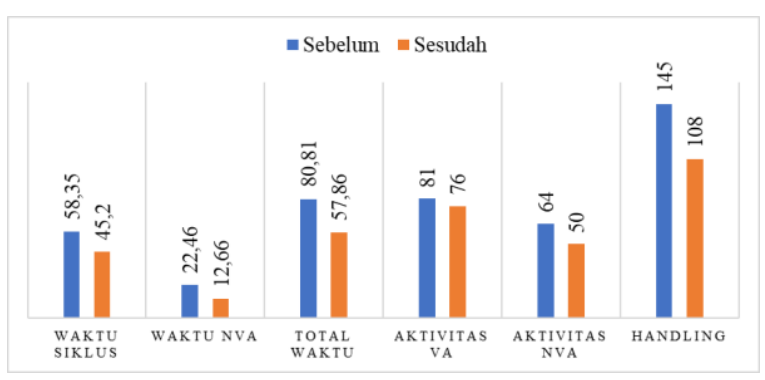

Gambar 7. Implikasi Penerapan Lean-Kaizen terhadap kinerja lini perakitan

Hasil ini tentu saja telah melebihi target harian. Peningkatan output tanpa melakukan penambahan input akan berdampak pada peningkatan produktivitas. Dengan memperhitungkan jumlah operator dan waktu kerja efektif selama 480 menit/hari sebagai input, dihasilkan proyeksi produktivitas lini perakitan setelah implementasi Lean-Kaizen mencapai $82 \%$. Pencapaian ini telah melebihi target produktivitas yang ditetapkan oleh perusahaan yaitu $70 \%$.

Capaian ini membuktikan bahwa VSM adalah alat yang efektif untuk mengungkapkan pemborosan dalam value stream. Selain itu, VSM mengarahkan peneliti untuk berfokus pada proses dan area yang membutuhkan perbaikan. Integrasi VSM sebagai salah satu alat dari lean manufacturing dengan kaizen memberikan manfaat yang lebih signifikan terhadap performansi lini perakitan. Pengimplementasian kaizen sebagai konsep perbaikan berkelanjutan mampu menghilangkan pemborosan yang terjadi dengan cara-cara sederhana dan mudah diaplikasikan oleh semua pihak yang terlibat.

\section{KESIMPULAN DAN SARAN}

Kasus yang diangkat pada penelitian ini memberikan best practice implementasi LeanKaizen untuk perbaikan lini perakitan manual. Penelitian ini bertujuan untuk meningkatkan performansi dari lini perakitan manual dengan 
membandingkan parameter-parameter lean, seperti waktu siklus, aktivitas yang memberi dan tidak memberi nilai tambah, dan produktivitas sebelum dan sesudah kaizen diterapkan. Hasil pengimplementasian LeanKaizen menunjukkan target harian dapat tercapai diikuti dengan peningkatan produktivitas melebihi standar perusahaan secara signifikan. Hasil ini dipengaruhi oleh penurunan waktu siklus, jumlah aktivitas, dan waktu NVA pada lini perakitan manufaktur.

Penelitian ini terbatas hanya pada satu lini perakitan dengan penyelesaian secara empiris tanpa menyertakan asumsi-asumsi ketidakpastian yang bisa saja terjadi. Pengaplikasian pada seluruh lini perakitan yang ada di sebuah industri manufaktur membuat masalah menjadi lebih kompleks. Oleh karena itu, menggabungkan permasalahan LeanKaizen dengan simulasi menjadi peluang besar untuk penelitian selanjutnya karena dapat menangkap seluruh kondisi di lantai produksi dengan penyelesaian yang cepat.

\section{DAFTAR PUSTAKA}

Al-Aomar, R., \& Hussain, M. 2018. An assessment of adopting lean techniques in the construct of hotel supply chain. Tourism Management, 69 (December 2015), 553-565.

Chowdary, B. V., \& George, D. 2011. Improvement of manufacturing operations at a pharmaceutical company: A lean manufacturing approach. Journal of Manufacturing Technology Management, 23(1), 56-75.

Correia, D., Silva, F. J. G., Gouveia, R. M., Pereira, T., \& Ferreira, L. P. 2018. Improving manual assembly lines devoted to complex electronic devices by applying Lean tools. Procedia Manufacturing, 17, 663-671.

Domingo, R., Álvarez, R., Peña, M. M., \& Calvo, R. 2009. Redesigning an assembly line through lean manufacturing tools. International Journal of Advanced Manufacturing Technology, 43(9-10), 949-958.

Douglas, J. A., Antony, J., \& Douglas, A. 2015. Waste identification and elimination in HEIs: the role of Lean thinking. International Journal of Quality and Reliability Management, 32(9), 970981.
Gidey, E., Beshah, B., \& Kitaw, D. 2014. Review on the evolving relationship between quality and productivity. International Journal for Quality Research, 8(1), 47-60.

Hamed, M., \& Soliman, A. 2020. Takt time: A Guide to the Very Basic Lean Calculation.

Karas, A., \& Ozcelik, F. 2021. Assembly line worker assignment and rebalancing problem: A mathematical model and an artificial bee colony algorithm. Computers and Industrial Engineering, 156 (December 2020).

Kiran, D. R. 2017. Kaizen and Continuous Improvement. In Total Quality Management : Key Concept and Case Studies (pp. 313-332).

Klimecka-Tatar, D., \& Shinde, V. 2019. Improvement of Manual Assembly Line Based on Value Stream Mapping (Vsm) and Efectiveness Coefficient. Quality Production Improvement - QPI, 1(1), 537-544.

Kundgol, S., Petkar, P., \& Gaitonde, V. N. 2020. Implementation of value stream mapping (VSM) upgrading process and productivity in aerospace manufacturing industry. Materials Today : Proceedings.

Luo, T., Wu, C., \& Duan, L. 2018. Fishbone diagram and risk matrix analysis method and its application in safety assessment of natural gas spherical tank. Journal of Cleaner Production, 174, 296-304.

Miqueo, A., Torralba, M., \& Yagüe-Fabra, J. A. 2020. Lean manual assembly 4.0: A systematic review. Applied Sciences (Switzerland), 10(23), 1-37.

Nasution, A. A., Siregar, I., Anizar, Nasution, T. H., Syahputri, K., \& Tarigan, I. R. 2018. Lean Manufacturing Applications in the Manufacturing Industry. International Conference on Mechanical, System and Control Engineering, 220, 15.

Nguyen, M. N., \& Do, N. H. 2016. Reengineering Assembly Line with Lean Techniques. Procedia CIRP, 40, 590595.

Oliveira, M. S., Moreira, H. D. A., Alves, A. C., \& Ferreira, L. P. 2019. Using lean thinking principles to reduce wastes in reconfiguration of car radio final assembly lines. Procedia Manufacturing, $41,803-810$. 
Omogbai, O., \& Salonitis, K. 2017. The Implementation of 5S Lean Tool Using System Dynamics Approach. Procedia CIRP, 60, 380-385.

Pena, R., Ferreira, L. P., Silva, F. J. G., Sá, J. C., Fernandes, N. O., \& Pereira, T. 2020. Lean manufacturing applied to a wiring production process. Procedia Manufacturing, 51(2020), 1387-1394.

Prashar, A. 2014. Redesigning an assembly line through Lean-Kaizen: An Indian case. TQM Journal, 26(5), 475-498.

Ravizar, A., \& Rosihin, R. 2018. Penerapan Lean Manufacturing untuk Mengurangi Waste pada Produksi Absorbent. Jurnal INTECH Teknik Industri Universitas Serang Raya, 4(1), 23.

Romero, L. F., \& Arce, A. 2017. Applying Value Stream Mapping in Manufacturing: A Systematic Literature Review. IFAC-PapersOnLine, 50(1), 1075-1086.

Ruben, B., Vinodh, S., \& Asokan, P. 2019. State of art perspectives of lean and sustainable manufacturing. International Journal of Lean Six Sigma, 10(1), 234256.
Sivaraman, P., Nithyanandhan, T., Lakshminarasimhan, S., Manikandan, S., \& Saifudheen, M. 2020. Productivity enhancement in engine assembly using lean tools and techniques. Materials Today : Proceedings, 33, 201-207.

Sutharsan, S. M., Mohan Prasad, M., \& Vijay, S. 2020. Productivity enhancement and waste management through lean philosophy in Indian manufacturing industry. Materials Today: Proceedings, 33(xxxx), 2981-2985.

Usubamatov, R., Riza, A. R., \& Murad, M. N. 2013. A method for assessing productivity in unbuffered assembly processes. Journal of Manufacturing Technology Management, 24(1), 123139.

Yerasi, P. I. of a M. A. 2011. Productivity Improvement Of A Manual Assembly Line (Issue August).

Zahraee, S. M., Tolooie, A., Abrishami, S. J., Shiwakoti, N., \& Stasinopoulos, P. 2020. Lean manufacturing analysis of a Heater industry based on value stream mapping and computer simulation. Procedia Manufacturing, 51(2019), 1379-1386. 